\title{
PERAMALAN LAJU INFLASI DENGAN METODE AUTO REGRESSIVE INTEGRATED MOVING AVERAGE (ARIMA)
}

\author{
Djawoto \\ djawoto0706@yahoo.co.id
}

\author{
Sekolah Tinggi Ilmu Ekonomi Indonesia Surabaya
}

\begin{abstract}
Auto Regression Integrated Moving Average (ARIMA) or the combination model of Auto Regression with moving average, is a linier model which is able to represent the stationary time series or non stationary time series. The purpose of this research is to forecast the inflation rate in November 2010 with the Consumer Price Index (CPI) by using ARIMA. The inflation indicator is very important to anticipate in making the Government's policy and decision as well as for the citizen is for the information to determine what to do in related with savings and investment. By looking at the existing criteria, it is determined that the best model is ARIMA $(1,1,0)$ or AR (1). Model ARIMA $(1,1,0)$, the coefficient value AR (1) is significant,which has the most minimum value of Akaike Info Criterion (AIC) and Schwars Criterion (SC) compare toARIMA $(0,1,1)$ or MA (1) and ARIMA $(1,1,1)$ or AR (1) MA (1). In summarize, the ARIMA model used to forecast the valueof IHK is ARIMA $(1,1,0)$.
\end{abstract}

Key words: Auto Regressive Integrated Moving Average (ARIMA), Inflation, Consumer Price Index (CPI).

\section{PENDAHULUAN}

Inflasi adalah masalah seluruh dunia. Namun berdasarkan data, negara yang sedang berkembang yang lebih banyak pengalamannya dalam hal inflasi dibanding dengan negara industri (Fery Andrianus, 2006). Penyebaran inflasi keseluruh dunia terjadi oleh karena adanya mekanisme perdagangan keuangan yang saling berkaitan antara negara dunia. Inflasi merembes keseluruh dunia dengan bebas (Goodfriend, 1990). Kenaikan harga minyak empat setengah kali pada tahun 1973 - 1974 telah meningkatkan laju inflasi dunia dengan cepat pada tahun 1974 - 1975 (Soeratno, 2004). Demikian juga perluasan "money supply" dunia pada tahun 1970 an telah mendorong inflasi. Kenyataan ini adalah akibat kekakuan "exchange rate". Bila exchange rate (nilai tukar), fleksibel sempurna maka inflasi dapat dihindari. Sebaliknya kebanyakan negara dunia memiliki 
tingkat penukaran mata uang asing (exchange rate) yang tidak fleksibel, sehingga inflasi tak dapat dihindari (Sukirno, 2000).

Generalisasi seperti ini tentu ada kecualinya, yaitu negara yang mempunyai sistem perencanaan sentral di Eropa Timur atau Uni Soviet (tempo dulu). Pada negara-negara ini harga ditetapkan oleh pemerintah pusat (secara administratif). Jadi bukan karena permainan permintaan dan penawaran (Suparmoko, 1990). Ini tidak berarti bahwa permintaan tidak pernah melebihi penawaran. Bila kenyataan ini juga terjadi maka penjatahan atau antri dapat diberlakukan terhadap produksi, sebelum penawaran ditingkatkan. Bahkan kadang-kadang dengan memberikan subsidi. Keadaan seperti ini disebut "represed inflation" (Winarno, 2007). Kelebihan permintaan diatas jumlah barang yang ditawarkan dikontrol oleh negara dan kenaikan harga dapat ditekan.

Inflasi dinegara-negara berkembang belahan barat didominasi oleh Amerika Latin (terutama Argentina, Chili, dan Uruguay). Salah satu negara di Asia yang telah mengalami inflasi hebat atau "hyperyinflation" adalah Indonesia yaitu tahun 1963 - 1971 dimana indeks harga telah naik dari 1000 menjadi 71797.

Berhubung kebanyakan negara yang menganut sistem ekonomi campuran, harga ditentukan oleh mekanisme pasar atau interaksi "supply" dan "demand" maka penyebab inflasi dapat diketahui dari dua hal atau dua sisi yaitu sisi demand dan sisi supply. Bila inflasi disebabkan oleh demand yang berlebihan disebut "demand pull inflation" sebaliknya bila yang ditekankan dari segi supply disebut "cost push inflation".

Inflasi yang terjadi karena kelebihan permintaan tersebut tergantung pula pada elastisitas supply. Bila elastisitas supply besar maka kenaikan harga itu akan diimbangi dengan kenaikan produksi sehingga kenaikan harga hanya terasa sedikit sekali. Dalam jangka pendek bila terdapat kapasitas menganggur (produksi bekerja dibawah kapasitas yang tersedia) dan devisa cukup banyak, maka kenaikan permintaan akan mendorong kenaikan produksi dan mendorong pula kenaikan barang impor. Dengan kata lain pengaruh kenaikan permintaan lebih besar pengaruhnya terhadap kenaikan produksi dibanding dengan kenaikan harga. Jadi "demand pulled inflation" akan lebih berbahaya bila terdapat "constrain" dalam hal devisa dan ekonomi telah berada pada posisi yang hampir "full employment".

Rumusan masalah dalam penelitian ini adalah bagaimana meramalkan inflasi untuk bulan Nopember 2010 dengan menggunakan methode Auto Regressive Integrated Moving Average (ARIMA).

Adapun tujuan dalam penelitian ini adalah untuk meramalkan besarnya inflasi yang terjadi pada bulan Nopember 2010 dengan menggunakan methode ARIMA. 
Sedangkan manfaat yang diharapkan dalam penelitian ini adalah bagi pemerintah dapat digunakan dalam menentukan langkah antisipasi dalam membuat kebijakannya dan bagi masyarakat, dapat digunakan sebagai informasi yang sangat penting untuk menentukan langkah-langkah yang harus diambil dalam hubungannya dengan tabungan dan investasi.

\section{RERANGKA TEORETIS}

Peramalan merupakan suatu unsur penting dalam memprediksi ketidak-pastian masa depan sebagai upaya membantu perusahaan atau pemerintah untuk mengambil keputusan yang lebih baik. Untuk melakukan peramalan, dibutuhkan data lampau (historis) dan memanipulasi data tersebut untuk mencari polanya yang secara efektif sehingga dapat ditarik ke masa depan. Salah satu teknik peramalan yang digunakan yaitu Metode BoxJenkins (ARIMA - Autoregressive Integrated Moving Average). Metode ini telah dipelajari secara mendalam dan dikembangkan oleh Bianco et al., (2001). Model Autoregresif (AR) pertama kali dikembangkan oleh Diebold dan Nerlove (1989) dan kemudian dikembangkan oleh Spyros (1995), sedangkan model Moving Average (MA) pertama kali digunakan oleh Weiss (1984).

Model Auto Regressive Integrated Moving Average (ARIMA) atau model gabungan autoregresi dengan rata-rata bergerak, adalah jenis model linier yang mampu mewakili deret waktu yang stasioner maupun non-stasioner. Pada metode peramalan dengan menggunakan Box-Jenkins (ARIMA-Autoregressive Integrated Moving Average), di mana sangat baik ketepatannya untuk peramalan jangka pendek, sedangkan untuk peramalan jangka panjang ketepatan peramalannya kurang baik, biasanya akan cenderung flat (mendatar/konstan) untuk periode jangka panjang (Philips dan Peron, 1988). Model ARIMA adalah model yang secara penuh mengabaikan independen variabel dalam membuat peramalan. ARIMA menggunakan data masa lalu dan sekarang dari variabel dependen untuk menghasilkan peramalan jangka pendek yang akurat.

Menurut Gujarati (2003), terdapat lima pendekatan dalam peramalam ekonomi berbasis data runtut waktu. Kelima pendekatan tersebut adalah: (1) exponential smoothing method, (2) single equation regression method, (3) simultaneous equation regression model, (4) autoregression integrated moving average (ARIMA), (5) vector autoregression. Model ARIMA merupakan gabungan antara AR (autoregressive) dan MA (moving average) yang sudah dideference. Konsep ini mendasarkan pada asumsi bahwa "data speak for themselves", karena nilai data pada masa sekarang dipengaruhi oleh nilai data pada masamasa sebelumnya.

Beberapa model yang cukup populer untuk melakukan analisis terhadap data runtut waktu ditunjukkan pada tabel 1 sebagai berikut: 
Tabel 1

Model-Model Analisis Terhadap Daya Runtut Waktu

\begin{tabular}{|c|c|}
\hline "MODEL & בASUMSI \\
\hline Autoregressive (AR) & $\begin{array}{l}\text { Data periode sekarang dipengaruhi oleh data } \\
\text { pada periode sebelumnya }\end{array}$ \\
\hline Moving Average & $\begin{array}{l}\text { Data periode sekarang dipengaruhi oleh nilai } \\
\text { residual data periode sebelumnya }\end{array}$ \\
\hline $\begin{array}{l}\text { Autoregrsessive Moving Average } \\
\text { (ARMA) }\end{array}$ & $\begin{array}{l}\text { Data periode sekarang dipengaruhi oleh data } \\
\text { pada periode sebelumnya dan juga oleh nilai } \\
\text { residual data periode sebelumnya }\end{array}$ \\
\hline $\begin{array}{l}\text { Autoregressive Integrated Moving } \\
\text { Average (ARIMA) }\end{array}$ & $\begin{array}{l}\text { Mirip dengan ARMA, kecuali data harus } \\
\text { didiference dulu. Diference inilah yang } \\
\text { membedakan ARMA dengan ARIMA }\end{array}$ \\
\hline
\end{tabular}

Sumber : Enders (1995)

Untuk dapat menentukan perubahan harga rata-rata yang berlaku pada suatu periode tertentu perlu dibentuk dan dihitung indeks harga. Terdapat tiga indeks harga yaitu indeks harga konsumen (consumer price index), indeks harga produsen (producer price index) dan pendeflasi gross domestic product (GDP deflator). Ketiga indeks harga ini dapat digunakan untuk menunjukkan tingkat inflasi yang berlaku dalam suatu periode tertentu. Tentunya sebagai akibat dari perbedaan jenis barang yang diamati, tingkat inflasi masingmasing indeks harga akan berbeda. Akan tetapi perbedaan tersebut tidak perlu dipandang serius karena tiap-tiap indeks memberikan gambaran inflasi untuk golongan barang yang berbeda. Dengan demikian tingkat inflasi yang ditentukan dengan menggunakan ketiga indeks harga tersebut saling melengkapi satu sama lain.

Salah satu peristiwa moneter yang sangat penting dan yang dijumpai di hampir semua Negara di dunia adalah inflasi. Inflasi adalah kecenderungan dari harga-harga untuk naik secara umum dan terus menerus (Boediono 1982). Inflasi dapat juga dikatakan sebagai penurunan daya beli uang, makin tinggi kenaikan harga makin turun nilai uang. Defenisi diatas memberikan makna bahwa, kenaikan harga barang tertentu atau kenaikan harga karena panen yang gagal misalnya, tidak termasuk inflasi. Syarat adanya kecenderungan menaik yang terus menerus juga perlu diingat. Kenaikan harga-harga karena, misalnya musiman, menjelang hari-hari besar atau yang terjadi sekali saja (dan tidak mempunyai pengaruh lanjutan) tidak disebut inflasi, karena harga semacam ini tidak dianggap sebagai masalah atau "penyakit" ekonomi dan tidak memerlukan kebijaksanaan khusus untuk menanggulanginya. Perkataan "kecenderungan" dalam definisi inflasi perlu digarisbawahi. Kalau seandainya harga-harga dari sebagian besar barang diatur atau ditentukan pemerintah, maka harga-harga yang dicatat oleh Badan Pusat Statistik mungkin tidak menunjukkan kenaikan apapun (karena yang dicatat adalah harga "resmi" pemerintah). Tetapi mungkin dalam realita ada kecenderungan bagi harga-harga untuk terus menaik. 
Keadaan seperti ini tercermin dari, misalnya adanya harga-harga "bebas" atau hargaharga "tidak resmi" yang lebih tinggi dari harga-harga "resmi" dan yang cenderung menaik. Dalam hal ini inflasi sebetulnya ada, tetapi tidak diperkenankan untuk menunjukkan dirinya. Keadaan seperti ini disebut "suppressed inflation" atau "inflasi yang ditutupi", yang pada suatu waktu akan timbul dan menunjukkan dirinya karena harga-harga resmi semakin tidak relevan bagi kenyataan. Ukuran inflasi yang paling banyak digunakan adalah: "consumer price indeks" atau "cost of living indeks". Indeks ini berdasarkan pada harga dari satu paket barang yang dipilih dan mewakili pola pengeluaran konsumen. Barang-barang dalam paket itu dibobot sesuai dengan kepentingan relatifnya bagi konsumen. Dan data harga diperoleh dalam bentuk indeksasi. Indeks yang lain juga dapat diperoleh dari "deflatoir GNP pada harga konstan". Kelebihan indeks ini bukan hanya memperhitungkan harga barang konsumen tetapi juga harga barang kapital dan barang ekspor.

\section{METODOLOGI PENELITIAN}

\section{Populasi dan Sampel Penelitian}

Penelitian ini menggunakan data sekunder yang berupa time series bulanan dari Indeks Harga Konsumen mulai tahun 2005-2010 yang berhasil dikumpulkan dari Badan Pusat Statistik.

\section{Identifikasi Variabel}

Dalam penulisan ini akan dianalisa model peramalan yang terbentuk dengan menggunakan metode Box-Jenkins di mana variabel yang digunakan adalah Indeks Harga Konsumen dari tahun 2005 sampai dengan2010. Sebelum membentuk sebuah model ARIMA pada suatu deret waktu maka harus dilakukan 4 proses yang dijalankan yaitu : Identifikasi Model, Estimasi Model, Pemeriksaan Model dan yang terakhir jika model sudah terbentuk adalah menggunakan model tersebut untuk prediksi pada masa mendatang. Berikut adalah aplikasi ARIMA berupa (1) mencari data deret waktu bulanan, sebanyak 68 bulan, (2) memanfaatkan data tersebut dan software pengolahan data deret waktu yang tersedia untuk menentukan model persamaan peramalan ARIMA pada variabel tersebut.

\section{Teknik Analisa Data}

Indeks Harga Konsumen (IHK) adalah angka indeks yang mengukur besarnya perubahan harga yang terjadi pada sekelompok barang dan jasa yang mewakili konsumsi masyarakat rata-rata di wilayah perkotaan. Dalam perhitungan IHK, angka yang di peroleh berasal dari indeks harga tertimbang dengan bobot (weight) banyaknya rumah tangga di wilayah tertentu. Bobot tersebut diperoleh pada tahun yang di jadikan tahun dasar dari angka indeks tersebut. Formula yang di gunakan Badan Pusat Statistik (BPS) dalam menghitung IHK adalah formula Laspeyres sebagai berikut: 


$$
\mathrm{IL}=\frac{\mathrm{P}_{\mathrm{t}} \cdot \mathrm{Q}_{\mathrm{o}}}{\mathrm{P}_{\mathrm{o}} \cdot \mathrm{Q}_{\mathrm{o}}} \mathrm{X} 100
$$

Keterangan:

$\mathrm{I}_{\mathrm{L}}$ : Indeks Laspeyres

$\mathrm{P}_{\mathrm{t}}$ : harga pada tahun yang di hitung

$\mathrm{P}_{\mathrm{o}}$ : harga pada tahun dasar

$\mathrm{Q}_{0}$ : kuantitas barang pada tahun dasar

Berdasarkan penghitungan IHK dengan formula Laspeyres, maka inflasi dapat di hitung dengan cara sebagai berikut:

Keterangan:

$$
\text { Inflasi }=\frac{\mathrm{IHK}_{\mathrm{t}}-\mathrm{IHK}_{\mathrm{t}-\mathrm{i}}}{\mathrm{IHK}_{\mathrm{t}-\mathrm{i}}} \times 100
$$

$\mathrm{IHK}_{\mathrm{t}} \quad$ : Indeks Harga Konsumen pada tahun yang di hitung

IHK $_{\mathrm{t}-\mathrm{I}} \quad$ : Indeks Harga Konsumen pada tahun sebelumnya

\section{ANALISIS DAN PEMBAHASAN}

Data sekunder yang berhasil dikumpulkan adalah Indeks Harga Konsumen dari tahun 2005 hingga 2010 seperti tampak pada Tabel 2. Data selanjutnya diolah dengan menggunakan software E-Views versi 2003. Penentuan model ARIMA nilai Indeks Harga Konsumen dimulai dengan uji stasioneritas dan autokorelasi variabel, serta identifikasi tingkat/derajat autoregresi (AR), integritas (I) dan Moving Average (MA) variable.

Tabel 2

Indeks Harga Konsumen Bulanan Indonesia, 2005, 2006, 2007, Jan-Mei 2008 (2002=100), Juni - Desember 2008, 2009, 2010 (2007 = 100)

\begin{tabular}{lcccccc}
\hline \hline \multirow{2}{*}{ Bulan } & $\mathbf{2 0 0 5}$ & $\mathbf{2 0 0 6}$ & $\mathbf{2 0 0 7}$ & $\mathbf{2 0 0 8}$ & $\mathbf{2 0 0 9}$ & $\mathbf{2 0 1 0}$ \\
\cline { 2 - 7 } & IHK & IHK & IHK & IHK & IHK & IHK \\
\hline Januari & 118.53 & 138.72 & 147.41 & 158.26 & 113.78 & 118.01 \\
Februari & 118.33 & 139.53 & 148.32 & 159.29 & 114.02 & 118.36 \\
Maret & 120.59 & 139.57 & 148.67 & 160.81 & 114.27 & 118.19 \\
April & 121.00 & 139.64 & 148.43 & 161.73 & 113.92 & 118.37 \\
\hline Mei & 121.25 & 140.16 & 148.58 & 164.01 & 113.97 & 118.71
\end{tabular}


Tabel 2 lanjutan

\begin{tabular}{lcccccc}
\hline \hline \multirow{2}{*}{ Bulan } & $\mathbf{2 0 0 5}$ & $\mathbf{2 0 0 6}$ & $\mathbf{2 0 0 7}$ & $\mathbf{2 0 0 8}$ & $\mathbf{2 0 0 9}$ & $\mathbf{2 0 1 0}$ \\
\cline { 2 - 7 } & IHK & IHK & IHK & IHK & IHK & IHK \\
\hline Juni & 121.86 & 140.79 & 148.92 & $\left.110.08^{*}\right)$ & 114.10 & 119.86 \\
Juli & 122.81 & 141.42 & 149.99 & 111.59 & 114.61 & 121.74 \\
Agustus & 123.48 & 141.88 & 151.11 & 112.16 & 115.25 & 122.67 \\
September & 124.33 & 142.42 & 152.32 & 113.25 & 116.46 & 123.21 \\
Oktober & 135.15 & 143.65 & 153.53 & 113.76 & 116.68 & 123.29 \\
November & 136.92 & 144.14 & 153.81 & 113.90 & 116.65 & \\
Desember & 136.86 & 145.89 & 155.50 & 113.86 & 117.03 & \\
\hline
\end{tabular}

Sumber: Badan Pusat Statistik

*)Sejak Juni 2008, IHK didasarkan pada pola konsumsi pada survei biaya hidup di 66 kota tahun $2007(2007=100)$. Uji stasioneritas dan autokorelasi data dilakukan dengan menggunakan analisis grafis, correlogram dan/atau Unit Root Test seperti tampak pada gambar 1 dan gambar 2 .

\begin{tabular}{|c|c|c|c|c|c|c|c|c|}
\hline Autocor & relation & Partial & Correlation & & $A C$ & PAC & Q-Stat & Prob \\
\hline I & & & כ & 1 & 0.908 & 0.908 & 60.288 & o.00o \\
\hline I & & & I & 2 & 0.824 & -0.005 & 110.66 & O_OOO \\
\hline I & ב & & I & 3 & o. 744 & -0.026 & 152.26 & o. 000 \\
\hline I & ت & & I & 4 & 0.667 & -0.021 & 186.23 & o_ooo \\
\hline I & $\exists$ & & I & 5 & 0.592 & -0.037 & 213.36 & o.000 \\
\hline I &  & & I & 6 & 0.523 & -0.008 & 234.87 & O_ooo \\
\hline I & 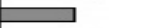 & & I & 7 & 0.457 & -0.023 & 251.60 & o.00o \\
\hline I & $\square$ & & I & 8 & 0.389 & -0.056 & 263.92 & o_ooo \\
\hline ' & $\square$ & & I & 9 & 0.325 & -0.030 & 272.64 & o. 000 \\
\hline I & $\square$ & & I & 10 & 0.270 & 0.011 & 278.77 & o.oOo \\
\hline ' & י & & I & 11 & 0.217 & -0.033 & 282.78 & o_ooo \\
\hline I & 曰 & & I & 12 & 0.165 & -0.035 & 285.14 & O_ooo \\
\hline & • & & I & 13 & o. 113 & -0.042 & 286.26 & o. 000 \\
\hline ' & 马 1 & & ' & 14 & o.062 & -0.043 & 286.61 & O_OOO \\
\hline I & I & & I & 15 & o.009 & -0.056 & 286.62 & o.000 \\
\hline I & I & & I & 16 & -0.041 & -0.039 & 286.78 & o.000 \\
\hline 1 正 & ' & & I & 17 & -0.090 & -0.046 & 287.55 & o. 000 \\
\hline 1며 & I & & I & 18 & -0.136 & -0.035 & 289.35 & O_OOO \\
\hline י & ' & & I & 19 & -0.176 & -0.020 & 292.41 & o. 000 \\
\hline ए & ' & & I & 20 & -0.213 & -0.033 & 296.97 & o.000 \\
\hline ᄃ & ' & & I & 21 & -0.246 & -0.032 & 303.20 & O. 000 \\
\hline 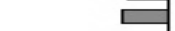 & ' & & I & 22 & -0.280 & -0.053 & 311.42 & o.000 \\
\hline$\square$ & ' & & ' & 23 & -0.313 & -0.054 & 321.93 & o. 000 \\
\hline 匹 & I & & I & 24 & -0.344 & -0.048 & 334.91 & o. 000 \\
\hline & I & & I & 25 & -0.371 & -0.035 & 350.35 & O_OOO \\
\hline & I & & I & 26 & -0.392 & -0.023 & 367.97 & O_OOO \\
\hline & I & & I & 27 & -0.413 & -0.052 & 387.93 & o. 000 \\
\hline & ' & ' & , & 28 & -0.435 & -0.067 & 410.60 & o.000 \\
\hline$\square$ & I & & י & 29 & -0.456 & -0.063 & 436.21 & o. 000 \\
\hline & I & & ק & 30 & -0.451 & 0.094 & 461.86 & O_OOO \\
\hline & I & & 10 & 31 & -0.448 & -0.051 & 487.84 & o. 000 \\
\hline$\square$ & I & ' & I & 32 & -0.442 & -0.030 & 513.81 & O_OOO \\
\hline
\end{tabular}

Gambar 1

Correlogram IHK pada level 0 


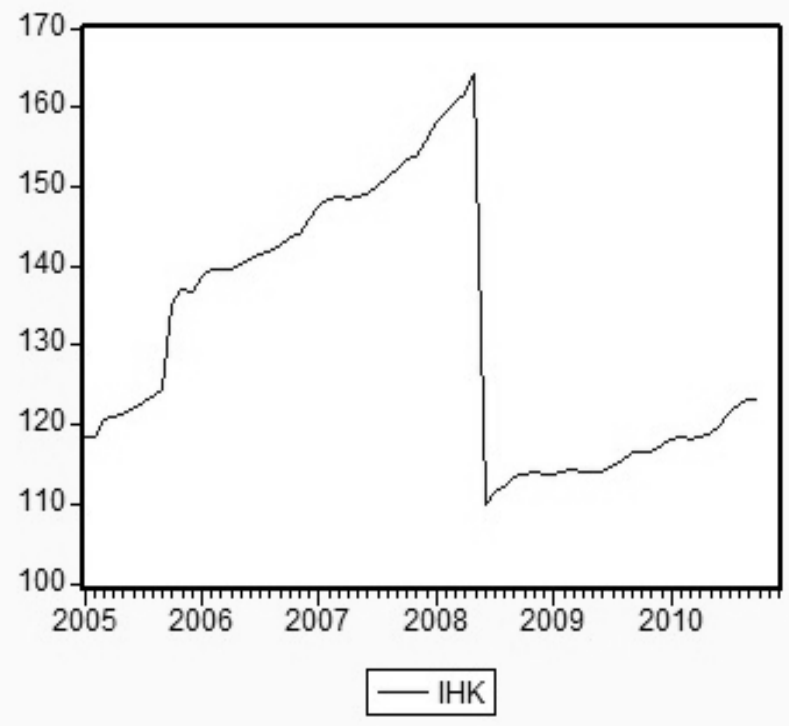

Gambar 2

Line Graph pada level 0

Dari gambar 1 dan gambar 2 tampak bahwa data tidak stasioner, ini dapat diketahui dari berbagai indikator berikut:

- Grafik autokorelasi pada lag pertama berada di luar garis Bartlett dan menurun secara eksponensial atau perlahan, semakin kecil dan bila diteruskan akan keluar lagi dari garis Bartlett, meskipun grafik batang berpindah ke sebelah kiri. Garis Bartlett adalah garis yang ditandai dengan garis terputus-putus di kanan kiri garis tengah, baik pada grafik autokorelasi maupun autokorelasi parsial.

- Nilai koefisien autokorelasi besar yaitu 0,908 (dari kemungkinan -1 hingga +1 ) Dan menurun secara perlahan-lahan.

- Nilai tatistik Q sampai pada lag ke 32 adalah 513,81, ini jauh lebih besar daripada nilai statistik Kai Kuadrat.

- Nilai probabilitas dari lag ke 1 hingga lag ke 32 yang sangat mendekati nol, berarti lebih kecil dari $=5 \%$.Dengan kata lain bahwa data tudak stasioner.

- Ini diperkuat bila kita melihat grafik garis (line graph) IHK yang hasilnya tidak mendatar, maka dipastikan bahwa data tidak stasioner.

- Bila dilihat dari uji akar unit atau unit root test (tabel 3) tampak bahwa nilai kritis $=5 \%$ adalah -2.908 yang lebih besar daripada nilai statistik -1.699501 (ADF Test Statistic < nilai kritis di semua level of significance) ini menunjukkan bahwa data tidak stasioner. 
Data nilai IHK juga berautokorelasi yang dilihat dari Correlogram. Autokorelasi (AC) semua seri data signifikan, bahkan ada seri data memiliki AC yang besar $(>|0,5|)$, yaitu pada seri pertama, kedua, ketiga, keempat, kelima dan keenam. Dari correlogram juga dapat diketahui bahwa derajat Autokorelasi adalah satu $(\mathrm{AR}=1)$ yang bisa dilihat dari adanya satu nilai Partial Auto Correlation (PAC) yang tinggi $(>|0,5|)$. Adanya beberapa seri data yang memiliki autokorelasi tinggi $(>|0,5|)$ menunjukkan adanya kemungkinan moving average.

Tabel 3

Unit Root Test IHK pada tingkat Level

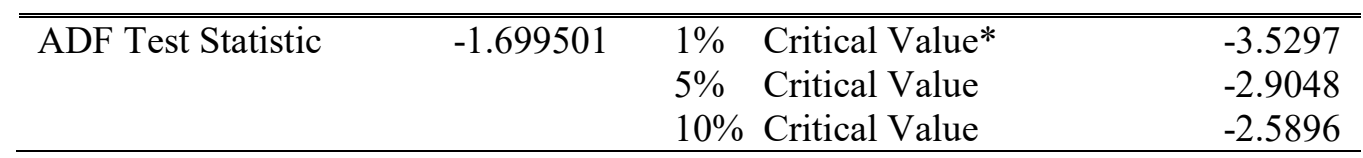

*MacKinnon critical values for rejection of hypothesis of a unit root.

Augmented Dickey-Fuller Test Equation

Dependent Variable : D(IHK)

Method: Leas Squares

Date: $11 / 26 / 10$ Time: $17: 10$

Sample(adjusted): 2005:04 2010:10

Included observations: 67 after adjusting endpoints

\begin{tabular}{crlcc}
\hline \hline Variable & Coefficient & Std. Error & t-Statistic & Prob. \\
\hline IHK(-1) & -0.090953 & 0.053517 & -1.699501 & 0.0942 \\
D(IHK(-1)) & 0.000712 & 0.126005 & 0.005653 & 0.9955 \\
D(IHK(-2)) & 0.028998 & 0.125563 & 0.230948 & 0.8181 \\
C & 12.01328 & 7.091926 & 1.693938 & 0.0952 \\
\hline R-squared & 0.045897 & Mean dependent var & 0.040299 \\
Adjusted R-squared & 0.000464 & S.D. dependent var & 6.836210 \\
S.E of regression & 6.834624 & Akaike info criterion & 6.739725 \\
Sum squared resid & 2942.862 & Schwarz criterion & 6.871348 \\
Log likelihood & -221.7808 & F-statistic & 1.010213 \\
Durbin-Watson stat & 2.000159 & Prob(F-statistic) & 0.394215 \\
\hline
\end{tabular}

Sumber: Data Sekunder diolah

Untuk menentukan derajat integrasi, maka data perlu distasionerkan terlebih dahulu, sebagai langkah awal dilakukan first difference pada nilai IHK. Hasil Correlogram, grafik dan uji kestasioneran data hasil first difference ini dapat dilihat pada gambar 3 dan gambar 4. 
Date: 11/26/10 Time: 08:15

Sample: 2005:01 2010:12

Included observations: 69

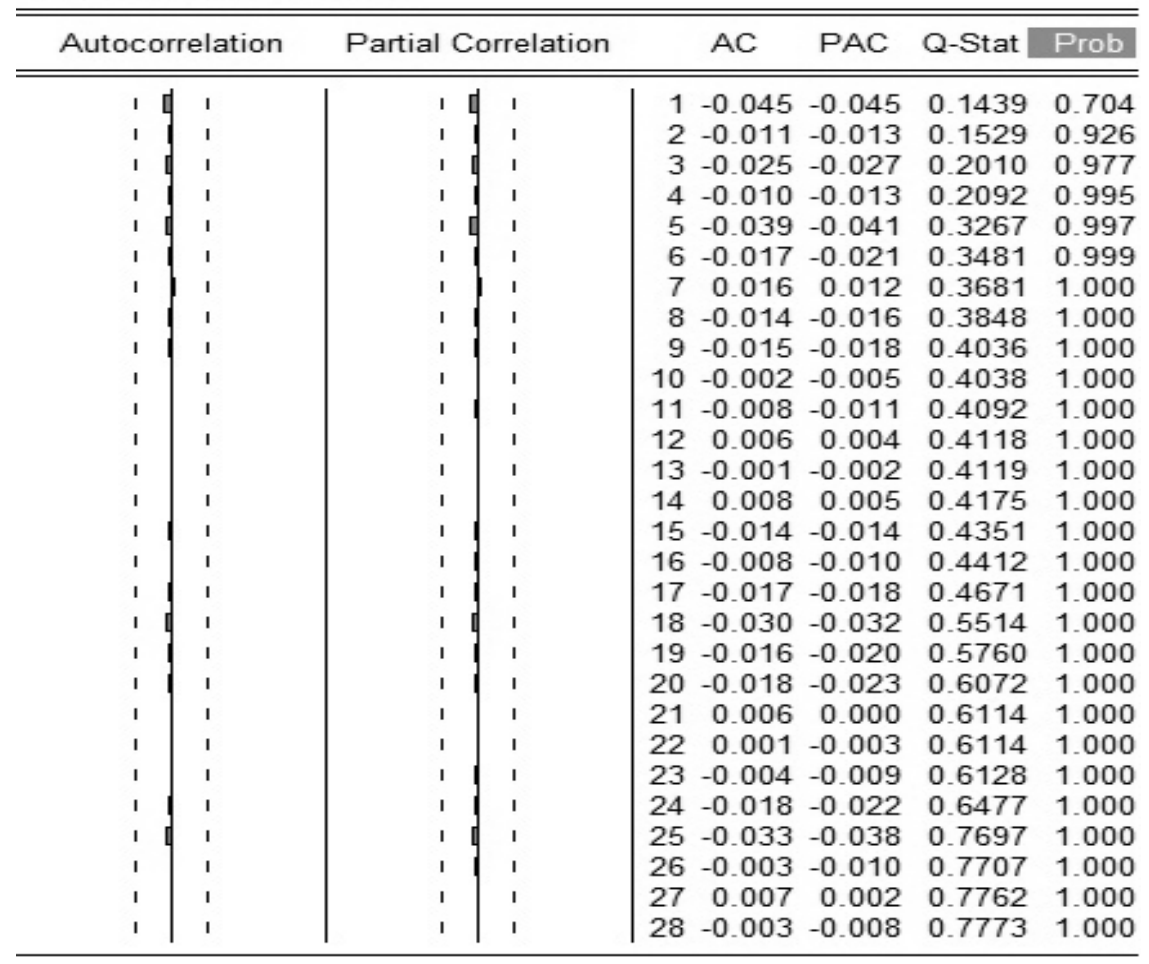

Gambar 3

Correlogram IHK pada tingkat First Difference

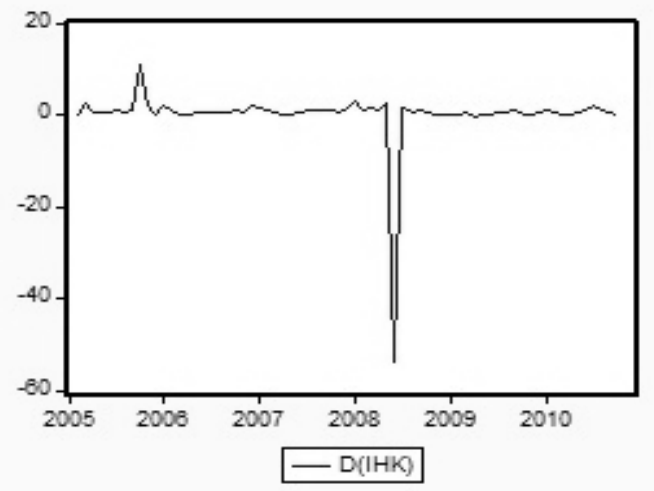

Gambar 4

Line Graph IHK pada First Difference 
Gambar 3 dan gambar 4 memperlihatkan bahwa data nilai IHK sudah stasioner. Ini dibuktikan oleh grafik garis yang bergerak di kisaran nilai tengah nol dan |ADF test statistic $|>|$ nilai kritis $\mid$ di semua level of significant. Dari correlogram juga dapat dilihat bahwa autokorelasi pada level first difference ini sudah tidak ada. Dengan demikian, dapat disimpulkan pula bahwa derajat integrasi dari Nilai IHK ini adalah satu $(\mathrm{I}=1)$.

Seperti telah dijelaskan sebelumnya, adanya autokorelasi yang signifikan pada data level awal (0) mengindikasikan adanya Moving Average. Untuk menentukan tingkat/derajat Moving Average dilakukan dengan ujicoba model yang ditunjukkan pada tabel 4.

Tabel 4

Unit Root Test IHK pada First Difference

\begin{tabular}{|c|c|c|c|c|}
\hline ADF Test Statistic & -4.780502 & \multicolumn{2}{|c|}{$\begin{array}{ll}1 \% & \text { Critical Value* } \\
5 \% & \text { Critical Value } \\
10 \% & \text { Critical Value }\end{array}$} & $\begin{array}{l}-3.5312 \\
-2.9055 \\
-2.5899\end{array}$ \\
\hline $\begin{array}{l}\text { *MacKinnon critica } \\
\text { Augmented Dickey- } \\
\text { Dependent Variable } \\
\text { Method: Leas Squar } \\
\text { Date: } 11 / 26 / 10 \text { Tim } \\
\text { Sample(adjusted): } 2 \\
\text { Included observatior }\end{array}$ & $\begin{array}{l}\text { ues for rejectio } \\
\text { er Test Equatio } \\
\text { HK,2) } \\
8: 28 \\
052010: 10 \\
6 \text { after adjustin }\end{array}$ & of hypothesi & f a unit root. & \\
\hline Variable & Coefficient & Std. Error & t-Statistic & Prob. \\
\hline IHK(-1) & -1.086710 & 0.227321 & -4.780502 & 0.0000 \\
\hline $\mathrm{D}(\operatorname{IHK}(-1), 2)$ & 0.040939 & 0.183524 & 0.223070 & 0.8242 \\
\hline $\mathrm{D}(\mathrm{IHK}(-2), 2)$ & 0.026630 & 0.126871 & 0.209898 & 0.8344 \\
\hline $\mathrm{C}$ & 0.038750 & 0.867007 & 0.044694 & 0.9645 \\
\hline R-squared & 0.522851 & Mean depen & nt var & -0.005000 \\
\hline Adjusted R-squared & 0.499763 & S.D. depend & var & 9.957842 \\
\hline S.E of regression & 7.042927 & Akaike info & terion & 6.800617 \\
\hline Sum squared resid & 3075.375 & Schwarz crit & & 6.933323 \\
\hline Log likelihood & -220.4203 & F-statistic & & 22.64613 \\
\hline Durbin-Watson stat & 2.000746 & Prob(F-stati & & 0.000000 \\
\hline
\end{tabular}

Saat derajat integrasi $=1$, ada tiga kemungkinan model, yaitu ARIMA $(1,1,1)$, ARIMA $(1,1,0)$ atau AR(1), dan ARIMA $(0,1,1)$ atau MA (1). Estimasi ketiga model persamaan harus dilakukan untuk menentukan model terbaik. Model yang terbaik adalah jika semua koefisien (AR atau MA) berpengaruh signifikan terhadap nilai variabel yang diamati (pada derajat integrasinya) dan/atau memiliki nilai Akaike Info Criterion (AIC) dan Schwarz Criterion (SC) paling kecil (minimum). Hasil estimasi ketiga model dapat dilihat pada tabel 5, 6 dan 7 berikut. 
Tabel 5

Hasil analisa model autoregressive AR (1)

Dependent Variable: IHK

Method: Leas Squares

Date: 11/26/10 Time: 19:20

Sample(adjusted): 2005:02 2010:10

Included observations: 69 after adjusting endpoints

Convergence achieved after 3 iterations

\begin{tabular}{lrllc}
\hline \hline \multicolumn{1}{c}{ Variable } & Coefficient & Std. Error & t-Statistic & Prob. \\
\hline \multicolumn{1}{c}{ C } & 132.0566 & 9.043076 & 14.60306 & 0.0000 \\
\multicolumn{1}{c}{ AR(1) } & 0.911586 & 0.049402 & 18.45229 & 0.0000 \\
\hline R-squared & 0.835578 & Mean dependent var & 131.3454 \\
Adjusted R-squared & 0.833124 & S.D. dependent var & 16.23899 \\
S.E of regression & 6.633709 & Akaike info criterion & 6.650762 \\
Sum squared resid & 2948.409 & Schwarz criterion & 6.715519 \\
Log likelihood & -227.4513 & F-statistic & 340.4871 \\
Durbin-Watson stat & 2.003875 & Prob(F-statistic) & 0.000000 \\
\hline Inverted AR Roots & 91 & & \\
\hline
\end{tabular}

Tabel 6

Hasil analisa model moving average MA (1)

Dependent Variable: IHK

Method: Leas Squares

Date: 11/26/10 Time: 08:53

Sample(adjusted): 2005:01 2010:10

Included observations: 70 after adjusting endpoints

Convergence achieved after 20 iterations

Backcast: 2004: 12

\begin{tabular}{lrllc}
\hline \hline \multicolumn{1}{c}{ Variable } & Coefficient & Std. Error & t-Statistic & Prob. \\
\hline \multicolumn{1}{c}{ C } & 131.1351 & 2.226984 & 58.88462 & 0.0000 \\
MA(1) & 0.746926 & 0.080458 & 9.283375 & 0.0000 \\
\hline R-squared & 0.570263 & Mean dependent var & 131.1623 \\
Adjusted R-squared & 0.563943 & S.D. dependent var & 16.19349 \\
S.E of regression & 10.69330 & Akaike info criterion & 7.605269 \\
Sum squared resid & 7775.578 & Schwarz criterion & 7.669510 \\
Log likelihood & -264.1844 & F-statistic & 90.23633 \\
Durbin-Watson stat & 0.969564 & Prob(F-statistic) & 0.000000 \\
\hline Inverted MA Roots & -79 & & \\
\hline
\end{tabular}

Peramalan Laju Inflasi Dengan Metode Auto Regressive Integrated Moving Average (Djawoto) 
Tabel 7

Hasil analisa model autoregressive integrated moving average $\operatorname{ARIMA}(1,1,1)$

\begin{tabular}{|c|c|c|c|c|}
\hline \multicolumn{5}{|c|}{$\begin{array}{l}\text { Dependent Variable: IHK } \\
\text { Method: Leas Squares } \\
\text { Date: 11/26/10 Time: 19:48 } \\
\text { Sample(adjusted): 2005:02 2010:10 } \\
\text { Included observations: } 69 \text { after adjusting endpoints } \\
\text { Convergence achieved after } 6 \text { iterations } \\
\text { Backcast: } 2005: 01\end{array}$} \\
\hline Variable & Coefficient & Std. Error & t-Statistic & Prob. \\
\hline $\mathrm{C}$ & 132.0614 & 9.134337 & 14.45768 & 0.0000 \\
\hline $\operatorname{AR}(1)$ & 0.912014 & 0.054272 & 16.80440 & 0.0000 \\
\hline $\mathrm{MA}(1)$ & -0.002640 & 0.134547 & -0.019619 & 0.9844 \\
\hline R-squared & 0.835579 & \multicolumn{2}{|c|}{ Mean dependent var } & 131.3454 \\
\hline Adjusted R-squared & 0.830596 & \multicolumn{2}{|c|}{ S.D. dependent var } & 16.23899 \\
\hline S.E of regression & 6.683755 & \multicolumn{2}{|c|}{ Akaike info criterion } & 6.679742 \\
\hline Sum squared resid & 2948.390 & \multicolumn{2}{|c|}{ Schwarz criterion } & 6.776877 \\
\hline Log likelihood & -227.4511 & \multicolumn{2}{|l|}{ F-statistic } & 167.7039 \\
\hline Durbin-Watson stat & 1.999313 & \multicolumn{2}{|c|}{ Prob(F-statistic) } & 0.000000 \\
\hline Inverted AR Roots & 91 & & & \\
\hline Inverted MA Roots & 00 & & & \\
\hline
\end{tabular}

Dengan kriteria yang ada, maka dari tabel 4, 5 dan 6 dapat dilihat bahwa model terbaik adalah ARIMA $(1,1,0)$ atau AR (1). Pada model ARIMA $(1,1,0)$, nilai koefisien AR (1) signifikan, dimana mempunyai nilai Akaike Info Criterion (AIC) dan Schwars Criterion (SC) yang paling minimum dibanding dengan ARIMA $(0,1,1)$ atau MA (1) dan ARIMA $(1,1,1)$ atau AR (1) MA (1). Dengan demikian, model ARIMA yang digunakan untuk meramal nilai IHK adalah ARIMA $(1,1,0)$.

Model ARIMA $(1,1,1)$ untuk data IHK dapat dituliskan dengan persamaan berikut:

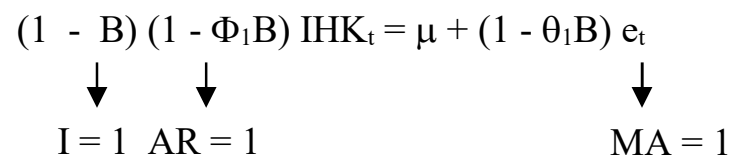

Jika diuraikan menjadi:

$$
\begin{aligned}
& \left(1-\Phi_{1} \mathrm{~B}-\mathrm{B}+\Phi_{1} \mathrm{~B}^{2}\right) \mathrm{IHK}_{\mathrm{t}}=\mu+\mathrm{e}_{\mathrm{t}}-\left(\theta_{1} \mathrm{~B}\right) \mathrm{e}_{\mathrm{t}} \\
& \mathrm{IHK}_{\mathrm{t}}-\left(1+\Phi_{1}\right) \mathrm{IHK}_{\mathrm{t}-1}+\Phi_{1} \mathrm{IHK}_{\mathrm{t}-2}=\mu+\mathrm{e}_{\mathrm{t}}-\theta_{1} \mathrm{e}_{\mathrm{t}-1} \\
& \mathrm{IHK}_{\mathrm{t}}=\mu+\left(1+\Phi_{1}\right) \mathrm{IHK}_{\mathrm{t}-1}-\Phi_{1} \mathrm{IHK}_{\mathrm{t}-2}-\theta_{1} \mathrm{e}_{\mathrm{t}-1}+\mathrm{e}_{\mathrm{t}} \\
& \text { dengan } \mu=\text { konstanta, } \Phi_{1}=\text { koefisien } \operatorname{AR}(1), \text { dan } \theta_{1}=\text { koefisien MA(1) }
\end{aligned}
$$


Dari hasil estimasi koefisien ARIMA $(1,1,0)$ atau AR (1) berarti, $\mu=132,0566$; $\Phi=$ 0.911586 dan $\theta_{1}=0$. Dengan demikian Model Persamaan ARIMA $(1,1,0)$ untuk nilai IHK adalah sebagai berikut:

$$
\mathrm{IHK}_{\mathrm{t}}=132,0566+1.911586 \mathrm{IHK}_{\mathrm{t}-1}-0.911586 \mathrm{IHK}_{\mathrm{t}-2}+\mathrm{e}_{\mathrm{t}-}
$$

Dengan menggunakan rumus model peramalan nilai IHK di atas, kita dapat memperkirakan nilai IHK di Indonesia pada bulan Nopember 2010 diperkirakan 133,0566. Dengan diketemukannya IHK bulan Nopember 2010 maka kita dapat menentukan besarnya Inflasi untuk bulan Nopember 2010 yaitu dengan rumus: (IHKt IHK t-1) $/$ IHKt-1 x $100=(133,0566-123,29): 123,29 \times 100=7,92 \%$.

\section{SIMPULAN}

Dari hasil analisis dan penerapan Auto Regressive Integrated Moving Average (ARIMA), kita dapatkan beberapa simpulan yang sangat penting untuk pengembangan lebih lanjut khususnya di bidang peramalan. Adapun simpulan yang diperoleh adalah sebagaiberikut:

1. Untuk menentukan besarnya inflasi, digunakan IHK yang merupakan angka indeks yang mengukur besarnya perubahan harga pada sekelompok barang dan jasa.

2. Peramalan dengan Auto Regressive Integrated Moving Average (ARIMA) merupakan metode yang tidak begitu rumit, namun mempunyai keakuratan dengan prosentase yang cukup besar.

3. Setelah dilakukan permalan dengan ARIMA besrnya IHK untuk bulan nopember 2010 diperkirakan sebesar 133,0566 (naik sebesar 7,2\%) dari bulan sebelumnya, ini dikarenakan bulan Nopember merupakan bulan menjelang perayaan hari Natal sekaligus Tahun Baru jadi dapat merangsang naiknya harga-harga.

Keterbatasan dalam penelitian ini adalah semua variabel yang mempengaruhi inflasi selain yang digunakan dalam penelitian ini dianggap konstan.

\section{DAFTAR PUSTAKA}

Bianco, A.M., Garc1'a, B.M., Mart1'nez, E.J. and Yohai, V.J. 2001. "Outlier detection in regressionmodels with ARIMA errors using robust estimates", Journal of Forecasting, Vol. 20 No. 8,pp. 565-79.

Boediono. 1982. Ekonomi Makro, BPFE, Yogyakarta.

Diebold, F.X. and Nerlove, M. 1989. "The dynamics of exchange rate volatility: a multivariate latent factor ARCH model", Journal of Applied Econometrics, Vol. 4 No. 1, pp. 1-21. 
Enders, W. 1995. Applied Economic Time Series, New York:John Wiley \& Sons.

Fery Andrianus. 2006. Analisa Faktor-faktor Yang Mempengaruhi Inflasi di Indonesia Periode 1997:3 - 2005:2, Jurnal Ekonomi Pembangunan vol 11, No 2.

Gujarati, Damodar N. 1995. Basic Econometrics, 3th edition, McGraw-Hill, Inc, Singapore.

Goodfriend, Marvin.1990. "Comments on Money Demand, Expectations and the Forward Looking Model.” Journal of PolicyModeling 12 (Z).

Phillips, P, and P. Perron. 1988. "Testing for a unit root in time series regression." Bimetrika, 75: 335-346.

Spyros, Steven, Victor. 1995. Forcasting, alih bahasa Untung, Abdul Basith, cetakan kelima,Erlangga, Jakarta.

Soeratno. 2004. Ekonomi Makro Pengantar, Bagian Penerbitan STIE YKPN, Yogyakarta.

Sukirno Sadono. 2000. Makroekonomi Modern, PT Raja Grafindo Persada, Jakarta.

Suparmoko. 1990. Pengantar Ekonomi Makro, BPFE UGM, Yogyakarta.

Weiss, A.A. 1984. ARMA models with ARCH errors", Journal of Time Series Analysis", Vol.5No. 2, pp. 129-43.

Winarno Wahyu W. 2007. Analisis Ekonometrika dan Statistika dengan Eviews. 